\title{
Impact of Use of European Union Structural Funds for Sustainable Development in Member States
}

\author{
Rimantas Dapkus and Dalia Streimikiene
}

\begin{abstract}
Structural Funds are the European Union's (EU) main instruments for supporting social and economic restructuring across the Union and sustainable development, ensuring convergence processes for the regions with different potential. Structural Funds account for over a third of the European Union budget. The aim of the presentation and paper is to review the use of $\mathrm{EU}$ structural funds for different programming periods and to identify the main achievements and challenges in ensuring sustainable economy growth and cohesion in EU. The main tasks to achieve this aim are: to analyze aims and financing priorities from EU structural funds and to compare the results of use of EU Structural funds in different EU member states.
\end{abstract}

Index Terms - Cohesion, EU structural funds, regional development, sustainable economy growth.

\section{INTRODUCTION}

Structural Funds are the European Union's main instruments for supporting social and economic restructuring across the Union. They account for over a third of the European Union budget. There are four Structural Funds: ERDF, ESF, EAGGF and FIFG, which contribute to the economic development of disadvantaged regions. A region may have access to one or more of the four structural funds, depending whether it has Objective 1, 2 or 3 status; all regions have Objective 3 status [1]. The aims of the funds, and in which priority 'Objective' area they can be spent, are set out below [2]:

The European Regional Development Fund (ERDF) aims to improve economic prosperity and social inclusion by investing in projects to promote development and encourage the diversification of industry into other sectors in areas lagging behind. This fund is available in Objective 1 and 2 areas.

The European Social Fund (ESF) funds training, human resources and equal opportunities schemes to promote employability of people in both Objective 1 and 3 areas. In Objective 2 areas ESF may be used to complement the ERDF activities.

The European Agricultural Guidance and Guarantee Fund (EAGGF) is available in rural Objective 1 areas to encourage the restructuring and diversification of rural areas, to promote economic prosperity and social inclusion, whilst protecting

Manuscript received July 18, 2014; revised April 10, 2016.

R. Dapkus is with the Institute of Public Policy and Administration at Kaunas University of Technology, K. Donelaicio str. 20, Kaunas, LT- 44239 Lithuania (e-mail: Rimantas.Dapkus@gmail.com).

D. Streimikiene is with the Vilnius University, Kaunas Faculty of Humanities, Socio-cultural Center, Muitines str. 8, Kaunas, LT-44280, Lithuania (e-mail: dalia@mail.lei.lt). and maintaining the environment and our rural heritage. In areas outside Objective 1, the EAGGF (Guarantee section) provides funding within the England Rural Development Plan.

The Financial Instrument for Fisheries Guidance (FIFG) funds projects to modernise the structure of the fisheries sector and related industries and to encourage diversification of the workforce and fisheries industry into other sectors. It also aims to ensure the future of the industry through achieving a balance between fisheries resources and their exploitation.

Most structural fund spending is targeted on specific regions, known as Objective 1 and 2 regions. There are separate national Objective 3 programmes in England, Wales, Scotland and Northern Ireland. The programmes must be approved by the Commission; set out below are the various stages in the approval process that programmes have reached [2].

Objective 1: Eligible areas are those that have less than $75 \%$ of EU average GDP. It is the highest level of regional funding available from the EU. It is aimed at promoting the development and structural adjustment of the EU regions most lagging behind in development.

Objective 2: Aims to support the economic and social conversion of areas facing structural difficulties. It is the second highest level of funding available from the EU. Areas qualify for Objective 2, under four strands - industrial, rural, urban and fisheries.

Objective 3: This Objective involves only the European Social Fund. It aims to develop labour markets and human resources and in addition, will help firms and workers adapt to new working conditions and so compete more effectively in global labour markets. It is directed at the long-term unemployed and those facing particular barriers to finding fulfilling employment because of their disability, racial origin, or sex.

In addition to the priority Objective areas around $5 \%$ of the Structural Fund budget fund four Community Initiatives. The current initiatives are [2]:

- EQUAL - funds training and employability schemes to combat discrimination and inequalities in the labour market:

- LEADER + - funds rural development projects;

- INTERREG - provides funding to encourage cross border, trans-national and interregional co-operation; to encourage balanced and sustainable development across the European Community.

- URBAN - funds schemes in small and medium sized towns suffering from significant economic and social conversion difficulties. 
EU structural funds are the main source of festering transitional countries', such as Lithuania among other new EU member states, economic growth and investing. It is expected that by making use of EU structural funds resources, Lithuania could catch up with some of the older EU member states in terms of the level of development by 2015. In 2005, the Lithuanian GDP per capita amounted to $47 \%$ of that of the EU-15 average. In Portugal this indicator was equal to $65.8 \%$, in Greece $-77 \%$, and in Spain - 90.7\%. The main aim of EU Structural funds to help countries to achieve sustainable development targets therefore the success of use of EU structural aid can be assessed by progress achieved towards sustainable development. Various indicators can be used to measures success of countries in implementing sustainable development, like human development index, welfare index or HPI (Happy Planet Index) measuring the extent to which countries deliver long, happy, sustainable lives for the people that live in them. The Index uses global data on life expectancy, experienced well-being and Ecological Footprint to calculate this. The index is an efficiency measure, it ranks countries on how many long and happy lives they produce per unit of environmental input.

The aim of the paper is to review the use of EU structural funds for first and second programming period and to identify the main achievements and challenges in ensuring stable economic growth and cohesion in EU and particularly in Lithuania as an example. The main tasks to achieve this aim is to analyse aims and financing priorities from EU structural funds in the first financing period in Lithuania; to analyse use of EU structural funds in second financing period in Lithuania and to generalise the results of these analyses by providing a comparative assessment of effectiveness of realized EU structural funds in the second financing period and development of HPI (Happy Planet Index) in Lithuania and other new EU member states.

\section{FIRST PRogramming PERIOD 2004-2006}

A National Plan was submitted by national governments to the European Commission in support of its request for aid from the Structural Funds in first programming period 2004-2006, that was eligible for the new EU member states since they have joined EU in 2004. For the purpose of consultation the countries are usually divided into sub-regions. The Plan generally proposes actions to improve the productive capacity of the economy; to encourage competitiveness and efficiency; to exploit the development potential of local initiatives, including area-based approaches targeted at disadvantaged areas; to develop skills and aptitudes of those seeking work; and to integrate those who are marginalised and disadvantaged into the workforce.

The official agreement between the Commission and the national governments on the amount and form of EU assistance for the National Development Plan takes the form of a Community Support Framework (CSF). The CSF contains a clause on environmental policy which states that all activities receiving EU funds must be in keeping with EU law and policies, including those on environmental protection. Member States are also obliged to supply the Commission with the appropriate information to enable them to evaluate the impact of operations or measures likely to have a significant impact on the environment.

The individual strategies outlined in the CSF, which in turn were based on the strategies outlined in the National Development Plan, are given practical expression by Operational Programmes which set out in more detail the particular measures which are assisted by the Structural Funds. The programmes are approved by the Commission and form the legal basis for the draw-down of assistance from the EU. Each programme is drawn up by the relevant Government Department or official agency [2].

EU structural support funds represent significant assistance to the modernisation and development of the transitional countries' economy. As an example, Lithuanian GDP per capita since joining EU in 2004 until now (2014) is below $75 \%$ of the European Union's average and all territory of Lithuania is classified under Objective 1 and is able to draw on support from the EU Structural Funds. Lithuania is also able to draw funds from Objective 2 and Objective 3. The Lithuanian Single Programming Document and its supplement for 2004 - 2006 defines the main strategy for the use of SF in Lithuania and is the final result of internal negotiations within Lithuania between many different public and non-public authorities as well as other stakeholders, followed by an intensive period of negotiations with the European Commission. The rules of EU Structural Funds Projects Administration and Financing were approved by the Minister of Finance on 31st May 2004.

The Lithuanian Single Programming Document (SPD) is being implemented by specific strategies described in five Operational Programmes (OPs) [3]:

- Development of social and economic infrastructure,

- Development of human resources,

- Development of productive sector and services,

- Rural development and fisheries,

- Technical assistance.

The main target or priority of Lithuanian SPD is to strengthen the preconditions for growth in long-term national economic competitiveness and to facilitate the transition to and development of a knowledge-based economy characterised by increasing GDP levels and strong employment growth, leading to higher living standards and increasing well-being for all Lithuania's inhabitants. There were five OP in Lithuania for the period 2004-2006 within the Community Support Framework. The total amount of SF support for 2004-2006 in Lithuania was 895.1 million EUR.

\section{SeCOND PROGRAMming PERIOD 2007-2013}

Total allocation of EU structural assistance for Lithuania for the period 2007-2013, provided from the European Social Fund, European Regional Development Fund and Cohesion fund, amounts more than 6 billion EUR. This equals to an additional annual state budget [3].

EU structural assistance for Lithuania for the period 2007-2013 is allocated in accordance with National general strategy: the Lithuanian Strategy for the use of European Union Structural Assistance for 2007-2013 (approved the 
European Commission on the 26th of April, 2007) and with operational programs for implementation of this strategy. An Operational Programme is the document submitted by a member state and approved by the European Commission with consistent priorities that can be implemented out of assistance funds. A specific action programme can be financed only by the European Social Fund or the Cohesion Fund and/or the European Regional Development Fund.

TABLE I: EU Structural Funds Allocated AND PAID IN LITHUANia IN 2007-2013 PROGRAMming Period

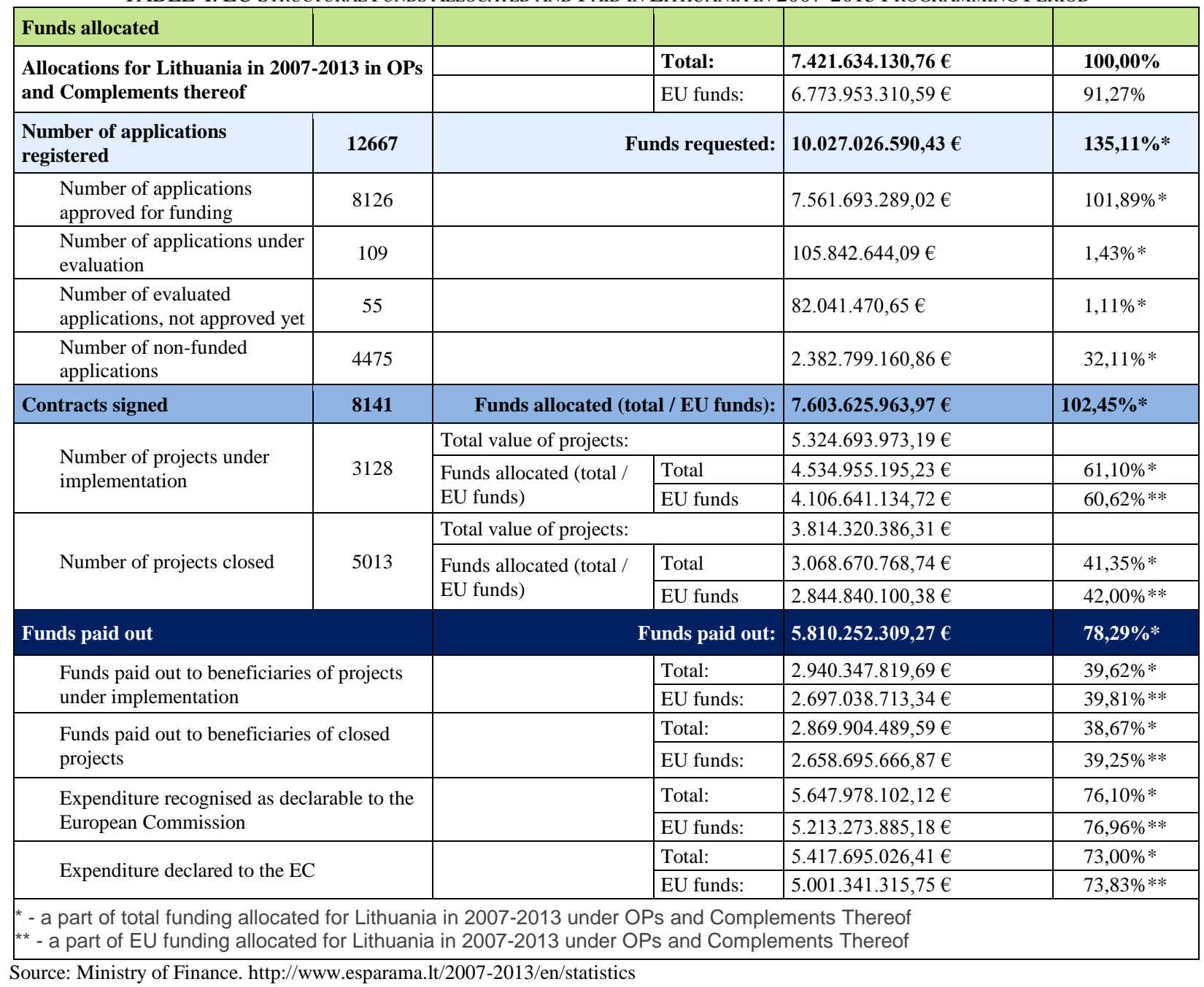

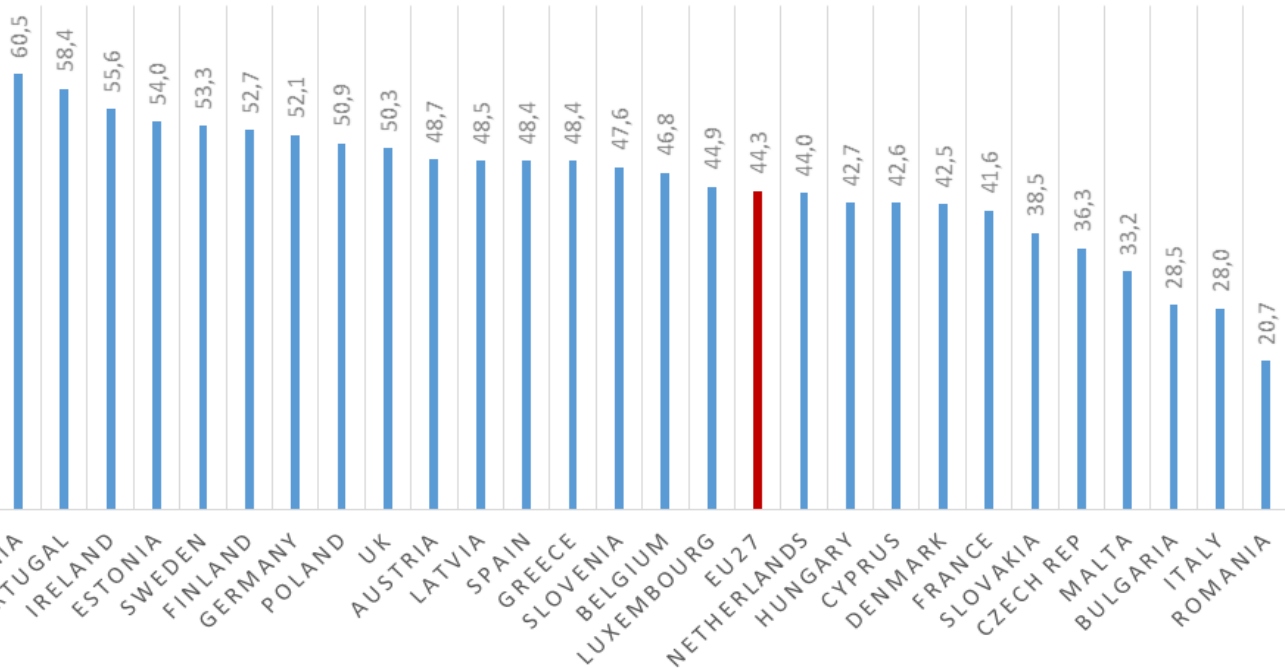

Fig. 1. Percentage of ERDF/ESF allocations reimbursed till 2013 July by the Commission for the 2007-2013 period.

The Resolution of the Government of the Republic of Lithuania of 14 December 2005 has approved the Strategy for the Use of EU Structural Funds in 2007-2013 and identified the Operational Programmes:
- Human Resources Development Operational Programme;

- Economic Growth Operational Programme;

- Cohesion Promotion Operational Programme. 
Primary purpose of employment of EU structural assistance, according to the strategy, is to rapidly improve conditions to invest, work and live in Lithuania, to support economy so its products would reach all citizens of Lithuania. Operational programmes support implementation of goals and tasks set in the strategy [4]. Operational Programme for the Development of Human Resources for 2007-2013 is dedicated to mobilization of all employable Lithuanian citizens, since investments to knowledge, competence, activity and enterprise of people of Lithuania ensures long term economic growth. $13.8 \%$ of EU structural funds are allocated to this program. It is estimated that the largest part of funds $-45.72 \%$ - allocated to Operational programme for the Economic Growth for 2007-2013. Extremely important is that $10 \%$ will was allocated to scientific researches and technological development of competitiveness and growth of economy. For improvement of environment and quality of residency, by minimizing differences between separate regions, it is allocated $39.08 \%$ of total funds from EU structural assistance for the period 2007-2013. Technical assistance Operational Programme for 2007-2013 - is a special program for administration of thematic programs of actions. $1.4 \%$ of EU structural funds were allocated for this programme.

The EU structural funds allocated and paid till 2013 July for 2007-2013 period in Lithuania are presented in Table I.

As one can see from information provided in Table II total EU funds allocated for Lithuania in 2007-2013 period makes more than 7.4 billion EUR. Contracts signed for 6.8 billion EUR and Funds paid out 4.4 billion EUR. The contracts signed refers to the funds of EU Funds and co-financing funds from the State budget of the Republic of Lithuania allocated for projects in project financing and administration contracts signed. The Funds paid out to the projects means the funds paid out to beneficiaries and contractors (service providers and suppliers of goods), including advance payments. Expenditure recognized as declarable to the EC - expenditure incurred by beneficiaries and verified by implementing bodies and recognized as eligible funds of the EU Funds and co-financing funds from the State budget of the Republic of Lithuania. Comparing with funding in 2003-2006 period which amounted to 895.1 MEUR sum allocated for the second period is significantly higher.

After analysis of EU member states reports on the progress of usage of the EU funds, it can be knottiest that Lithuania is leading (Fig. 1).

This information allows to evaluation each beneficiary country efforts to use the financial aid for the fastest implementation of the prepared projects for the sustainable regional development. On the experience and achieved results there is ongoing preparation for the next programming period.

The European Commission has adopted a draft legislative package which will frame cohesion policy for 2014-2020. The new proposals are designed to reinforce the strategic dimension of the policy and to ensure that EU investment is targeted on Europe's long-term goals for growth and jobs ("Europe 2020"). Through Partnership Contracts agreed with the Commission, Member States will commit to focussing on fewer investment priorities in line with these objectives. The package also harmonises the rules related to different funds, including rural development and maritime and fisheries, to increase the coherence of EU action.

The discussions on the new policy priorities for next programming period 2014-2020 are gaining acceleration in Lithuania. Based on the results of previous evaluations, major challenges for the next programming period are related to the innovation demand-side policies, internationalization, entrepreneurship, innovation support services, and ensuring the sustainability of large scale $R \& D$ infrastructure development projects launched during this period (e.g. the integrated science, business and studies 'valleys' projects. This is laid out on the Comparative assessment of EU structural funds support impact on the sustainable development.

\section{COMPARATIVE ASSESSMENT OF EU STRUCTURAL FundS SUPPORT IMPACT ON SUSTAINABLE DEVELOPMENT IN LITHUANIA AND OTHER NEW EU MEMBER STATES}

EU funded projects are expected to contribute to sustainable development. Realization of projects in bigger percentage is assigned to more developed countries with better project management knowledge [4]. However it is still not clear the efficiency of use of EU structural aid in implementing sustainable development [5].

The absorption of EU funds is a measurement of the EU funds usage, but also a measurement of fulfillment of the task to accelerate development of the states, and build a common European cohesion. Specific importance of the EU funds, which is often neglected, may be considered as a focus on development of certain sectors. By pushing the development of certain areas, EU funds can contribute to the long-term development and survival of European countries and its citizens. This aspect should be taken in consideration. It is necessary to discuss the use of EU funds from the view of forcing sustainable development of the EU countries and the whole EU. This is a new approach that considers EU funded project management as a specific process. The measure of its success can be analyzed in different ways [6].

The relationship between Happy Planet Index which reflects sustainable development of countries was applied as indicator to assess the effects of projects implemented through EU funded programs. It was expected that HPI should show if such financed projects satisfy target of the EU to protect the environment and ensure sustainable development of the country. Happy Planet Indexes are published by NEF every year for different countries. The HPI index does not necessary reveal the country with the highest level of happiness in the world. However, it indicates the relative efficiency of the nations, when they convert the planet's natural resources into long and happy lives for their citizens. It also shows that there are different ways to achieve comparable levels of well-being. The model followed by the West can provide widespread longevity and variable life satisfaction, but it does so only at a vast and ultimately counter-productive cost in terms of resource consumption [7].

The HPI explains the economy perspective right back to its basic simplicity: what we input (resources), and what are the output (human lives of different length and different levels of happiness). The HPI value of each country is calculated as a function of it's: 
- Average subjective life satisfaction,

- Life expectancy at birth,

- Ecological footprint per capita.

In Table II, HPI index and EU Structural Funds support per capita in 2007-2013 in new EU member states are presented.

As one can see from the Table II there is no relationship between the sum of EU structural funds allocated per capita during second financing period and HPI growth. Though Lithuania has received comparable high aid from EU structural funds per capita in 2007-2013 according HPI Lithuania is ranked at lower rate than Poland which has received less EU structural fund support per capita in 2007-2013. However one can noticed that in 2009 Lithuanian HPI has significantly increased from year 2006 but in 2012 decreased again. Estonia has received the highest support from EU structural funds however has quite low HPI. HPI was growing during 2006-20012 period just in Hungary and Czech Republic. In other new EU member states HPI has decreased though countries have received significant support for EU structural Funds. Of course economic crisis have impact on economic situation in countries and average subjective life satisfaction has declined during the crisis.

TABLE II: ReAlized EU StRuctural FundS PER CAPITA 2007-2013 AND DEVELOPMENT OF HPI In NEW EU MEMBER STATES

\begin{tabular}{|l|c|c|c|c|}
\hline Country & Realized EU structural funds per capita, 2007-2013, EUR & HPI 2006 & HPI 2009 & HPI 2012 \\
\hline Romania & 1102 & 37,7 & 43,9 & 42,2 \\
\hline Bulgaria & 911 & 31,6 & 42,0 & 34,1 \\
\hline Slovakia & 2128 & 35,8 & 43,5 & 40,1 \\
\hline Estonia & 2541 & 22,7 & 38,3 & 34,9 \\
\hline Poland & 1743 & 39,29 & 42,8 & 42,6 \\
\hline Czech Republic & 2504 & 36,5 & 38,3 & 39,4 \\
\hline Latvia & 2227 & 27,7 & 36,7 & 34,9 \\
\hline Lithuania & 2253 & 29,9 & 40,9 & 34,6 \\
\hline Hungary & 2503 & 38,9 & 38,9 & 37,4 \\
\hline Slovenia & 1995 & 44,03 & 44,5 & 40,2 \\
\hline
\end{tabular}

Source: http://www.happyplanetindex.org/public-data/files/happy-planet-index-first-global.pdf

There was also investigated the impact of EU structural support per capita impact on GHG emissions and other indicators and didn't find positive correlation between EU structural support per capita and these indicators [8], [9]. Of course such type of analysis has limitation and additional indicators need to be explored in more details.

Lithuania is viewed as a relatively closed society with insufficient conditions for the development and expression of creativity:

- 26th among the EU member states in the index of (economic, social and political) globalisation;

- $\quad 17$ th - by creativity, 24th - by climate for creativity;

- Low engagement in life-long learning - 21st place in the EU (only 5\% of those aged 25-74 were engaged in 2012);

- Relatively few dropouts from secondary schools and high involvement in the tertiary education (48\% in 2012 in the age category of 30-34 year olds), but the highest skills mismatch in the EU;

- Few students (15 year olds) achieving top performance in reading, mathematics and natural sciences $(0.1 \%$, $1.3 \%$ and $0.4 \%$ of the age cohort respectively);

- Rural-urban divide is still widespread and it affects educational attainment, the risk of being in social exclusion;

- Only $23 \%$ (twice as low as the EU average) of Lithuanians are very proud of the citizenship of Lithuania; $60 \%$ of them feel unnecessary in the society and $50 \%$ Lithuanian population would emigrate given a chance.

- Trust in political institutions (except the President's Office) is very low: only $4.2 \%$ trust political parties, $8.2 \%$ - Parliament and $23.3 \%$ - the Government.

This information defined from the Comparative assessment of EU structural funds support impact on the sustainable development of the country should be taken into account while making new strategies and programs for the EU aid.

\section{CONCLUSION}

1) EU Structural Funds is a good tool which can be used in new member states to attract investments for the financing of new technologies, including use of renewable energy sources and energy efficiency improvements (renewable energy projects) which are doubly underpowered by energy markets and needs state support.

2) Lithuanian benefited in the first programming period 2003-2006 by 895.1 MEUR from EU structural Funds and by 7.4 billion EUR in second programming period 2007-2013.

3) Operational Programmes (OPs) of the Structural Fund implementation in Lithuania during 2007-2013 have not sufficiently explored the chance to invest into innovation demand. The potential to link the demand for modernization to improve internal innovation capability is thus not fully realized.

4) The preparation for the current period (2007-2013) took longer than expected, consequently causing a significant delay in the implementation of most policy measures (some were delayed by 2-4 years).

5) The discussions on the new policy priorities for next programming period 2014-2020 have not been finished in time in Lithuania. Based on the results of previous evaluations, major challenges for the next programming period are related to the innovation demand-side policies, internationalization, entrepreneurship, innovation support services, and ensuring the sustainability of large scale R\&D infrastructure development projects launched during this period (e.g. the integrated science, business and studies 'valleys' projects).

6) Some empirical results showed that contribution of the 
EU funded projects is still not sufficient to make a significant influence on the sustainable development of the country. As other type projects which don't have this goal prevail.

7) There are no relationship between the sum of EU structural funds allocated per capita during second financing period and HPI growth in new EU member states. Though countries have received significant aid from EU structural funds almost in all countries HPI has declined during investigated period.

\section{REFERENCES}

[1] A. Horvat and G. Maier, "Absorption problems in the EU structural funds," Ljubljana, NARG, Strukturnifondovi, pp. 112-135, 2004.

[2] D. Štreimikienè, V. Klevas, and J. Bubelienè, "Use of EU structural funds for sustainable energy development in new EU member states," Renewable and Sustainable Energy Review, vol. 11, iss. 6, pp. 1167-1187, 2007.

[3] V. Kvainauskaite and V. Kardokaitè, "Structural funds as instruments for regional economic development in Lithuania," Engineering economics, vol. 2, no. 42, pp. 26-34, 2005.

[4] B. Melnikas, "The global transformations, sustainable development and the knowledge based society creation: The perspective theoretical approach," Business \& Economics, vol. 10, no. 2, pp. 151-168, 2011.

[5] V. Marinov, H. Bahloul, and B. Slay, "Structural funds and the new member states: lessons learned," London, Development \& Transition, UNDP, London School of Economics, issue 4, p. 97, 2006.

[6] EU funds in Central and Eastern Europe (CEE), Progress Report 2007-2012, Budapest, KPMG, p. 48, 2013.

[7] J. Bachtler, C. Mendez, and H. Oraže, "From conditionality to europeanization in central and eastern Europe: Administrative performance and capacity in cohesion policy," European Planning Studies, vol. 22, no. 4, pp. 735-757, 2014.

[8] M. Kranjac, R. Maksimović, and U. Sikimić, "A model of using IPA funds for project realization in pre-accession countries: The case of Serbia," Economics, vol. 89, no. 2, pp. 115-123, 2010.

[9] M. Kranjac, C. Heny, and U. Sikimić, "European funds as fact of sustainable development in central eastern European countries, facta universitatis," Series: Economics and Organization, vol. 8, no. 3, pp. 301-312, 2011.

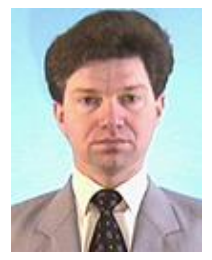

Rimantas Dapkus was born in Lithuania in 1959. In 1982 he has graduated from Kaunas Polytechnic Institute (at present Kaunas University of Technology) and became a diploma engineer in computing sciences. In 1995 he obtained a degree of doctor of the technical sciences and in 2009 became an assoc. professor of the social sciences at Kaunas University of Technology (Kaunas, Lithuania).

$\mathrm{He}$ has started his scientific carrier at Kaunas Polytechnic Institute faculty of Computer Science since 1980, later continued his researcher's and teacher's work in electro-technical and mechanical faculties, focusing on the nanotechnologies and mechatronics. Since 2000 until now he continues his researcher's and teacher's work in Faculties of Economics and Management and Social Sciences at Kaunas University of Technology, focusing on the innovations, regional development and economy. Since 2003 he has started his carrier at the Lithuanian Regional Research Institute and at present he is the president of this Institute, located in Lithuania, Kaunas, K. Donelaicio str. 60 . He has published over 30 papers in peer reviewed journals and conference proceedings, as well 8 books for the students.

Asoc. Prof., Dr. Rimantas Dapkus research interests are regional politics, sustainable economy grow, strategy planning, public administration, rural and cities planning, marketing, finances, innovations, project management, human resources, e-democracy, as well as industry development and automation, nanotechnologies and mechatronics. He also provides consultation for National and Regional authorities in the field of sustainable development and strategy planning, national and international programs development and projects implementation, consultation of private companies on business development issues. For his outstanding activities has been granted with Diplomas of the Lithuanian Supreme Council and American Institute of Bibliography

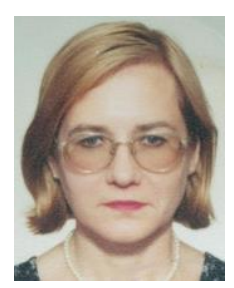

Dalia Streimikiene was born in Lithuania in 1962. In 1985 she graduated from Kaunas Polytechnic Institute (at present Kaunas University of Technology) and became a diploma engineer-economist. In 1997 she obtained a degree of doctor of the social sciences and in 2005 she passed the procedures of habilitation in social sciences at Vilnius Gediminas Technical University (Vilnius, Lithuania).

She has started her scientific carrier in 1985 at the Lithuanian Energy Institute and continues her work there as a senior researcher until now. Since 1997 she is a professor of Vilnius University Kaunas Faculty of Humanities and she has been involved in research dealing with sustainable economic development since 1998. The main sphere of her interest is environmental policies and their impact on sustainable economic development. She is included in the expert's roster of United Nations Climate Change Convention (UNFCCC) on GHG emission inventories, assessment of climate change policies and measures in energy sector. She has been regularly invited to work as an expert on sustainable development, climate change mitigation and environmental issues for European Commission, United Nations Economic Commission for Europe, United Nations Development Program, UNFCCC Secretariat, World Energy Council, Nordic Council of Ministers etc. She provides also consultancy services for Ministry of Environment and takes part in preparation on National communications to UNFCCC.

Prof. Dr. Dalia Streimikiene has big experience in international and local project management. During the last years she has won tenders and successfully lead studies on climate change mitigation policies development in Lithuanian energy sector. Also she led the international project financed by Nordic Council of Ministers "The Challenges of Kyoto protocol for Baltic States Energy Sectors" conducted together with researchers from Latvia and Estonia (2005-2006). Dalia Streimikiene was involved in the several important coordinated research projects financed by International Atomic Energy agency (IAEA): "Sustainable energy development indicators, (2002-2005); "GHG emission reduction strategies and energy supply options (2006-2009); "Comparative assessment of geological nuclear waste and CO2 storage (2009- 2012). Also she has been involved in the following EC FM 6 and 7 Projects: Cost Assessment for Sustainable Energy Systems, CASES (2006-2008); Probabilistic Long Term Assessment of Energy Scenarios, PLANETS (2008-2010). D. Streimikiene has published about 100 papers in peer reviewed journals. 